\title{
Non-legume plant species effects on soil nematodes abundance in a Regosol ${ }^{1}$
}

\author{
Tancredo Souza ${ }^{2}$, Lucas Sombra Barbosa ${ }^{3}$, Edjane Oliveira de Lucena ${ }^{4}$, Luan Nunes de Melo ${ }^{3}$, \\ Guilherme Silva de Podestá ${ }^{5}$, Djail Santos ${ }^{4}$
}

\begin{abstract}
The effects of a non-legume cover crop on total soil nematode abundance and soil groups of nematodes were investigated in a long-term field study. We compared total abundance of soil nematode and the abundance of both free-living soil nematode and root-feeding soil nematode under three different treatments (Pennisetum glaucum (L.) R. Br., native weeds and Caatinga moist-forest enclaves treatments) in a long-term field study cultivated on a Regosol. We found the highest abundance of free-living soil nematode in the Caatinga moistforest enclaves treatment, whereas the highest abundance of root-feeding nematode was found in the native weeds treatment. We did not find any difference among $P$. glaucum and native weeds treatments for total abundance of soil nematode. Our findings suggest that the introduction of $P$. glaucum in sandy soil of Brazilian semiarid can increase the abundance of free-living nematode, but in other hand this cover crop did not reduce the abundance of root-feeding nematode. Our results also highlight the importance of considering the identification of soil nematode groups as indicator of soil quality and impacts of soil management.
\end{abstract}

Keywords: free-living nematode; long-term field experiment; Pennisetum glaucum (L.) R.Br.; root-feeding nematode; sandy soil.

\section{Efeito de plantas não-leguminosas sobre a abundância de nematoides em Regossolo}

Resumo: O efeito do cultivo de espécies de plantas não-leguminosas sobre a abundância total de nematoides foi avaliado em um estudo de longa-duração em condições de campo. Objetivou-se comparar a abundância total de nematoides e a abundância de grupos funcionais de nematoides no solo (vida livre e fitopatogênicos) submetidos a três tratamentos (Pennisetum glaucum (L.) R.Br., vegetação espontânea e enclaves de floresta úmida na Caatinga) em um experimento de campo de longa-duração cultivado em um Regossolo. A maior abundância de nematoides de vida livre foi observada nas parcelas localizadas nos enclaves de Floresta úmida na Caatinga, enquanto a maior abundância de fitonematoides foi observada nas parcelas onde havia vegetação espontânea. Não foi observado diferenças significativas entre os tratamentos $P$. glaucum e vegetação espontânea para a abundância total de nematoides. Conclui-se que a introdução de $P$. glaucum como planta de cobertura em solos arenosos pode aumentar a abundância de nematoide de vida livre, no entanto a cultura não é eficaz em controlar a população de fitonematoides presentes no solo. Os resultados obtidos neste estudo também ressaltam a importância de considerar a identificação de grupos funcionais de nematoides como indicadores de qualidade do solo e impactos do manejo do solo.

Palavras-chave: Experimento de campo de longa-duração; Nematoides de vida livre; Nematoides fitopatogênicos; Pennisetum glaucum (L.) R. Br.; Solos arenosos.

\footnotetext{
${ }^{1}$ Submetido em 25/04/2018 e aprovado em 18/08/2019;

${ }^{2}$ Programa de Pós-Graduação em Ecossistemas Agrícolas e Naturais, Universidade Federal de Santa Catarina, Curitiba, Santa Catarina, Brasil; E-mail: tancredo.souza@ufsc.br - ORCID: 0000-0001-8729-5478;

${ }^{3}$ Programa de Pós-Graduação em Agronomia, Universidade Federal da Paraíba, Areia, Paraíba, Brasil; E-mail: lucas_sombra16@hotmail.com; luannunesdemelo@gmail.com;

${ }^{4}$ Programa de Pós-Graduação em Ciência do Solo, Universidade Federal da Paraíba, Areia, Paraíba, Brasil; E-mail: edjanelucenaengflo@gmail.com; santos.djail@gmail.com - ORICD: 0000-0003-2207-3115;

${ }^{5}$ Departamento de Fitotecnia e Ciências Ambientais, Universidade Federal da Paraíba, Areia, Paraíba, Brasil; E-mail: guilherme @cca.ufpb.br - ORICD: https://orcid.org/0000-0003-1613-7178.
}

Agropecuária Técnica, Areia-PB, v. 40, n. 1-2, p. 1-6, 2019

https://doi.org/10.25066/agrotec.v40i1-2.39488 


\section{Introduction}

The practice to use non-legume cover crops in agricultural areas is the main activity to reduce soil erosion and nutrient leaching in agroecosystems (Droppelmann et al., 2017). Understanding their characteristics to control root-feeding nematodes and to promote freeliving nematodes in a disturbed soil is essential to predict how this management practice can significantly increase soil organism community in Brazilian smallholder farming systems. Over time, this farming system in sandy soils cause soil quality decline and changes in soil organism community, such as soil nematodes community (Barel et al., 2017; Geisen et al., 2018; Hilton et al., 2018). Thus, research addressing non-legume cover crops as a management alternative to control root-feeding nematodes are essential.

Our work addressed the following question: If we reduce the abundance of host-plants by rootfeeding soil nematode using a non-legume plant species as cover crop, we could decrease the abundance of this functional group of soil roundworms? Based on the work done by Geisen et al. (2018) and Barel et al. (2017), we expected to find a lower abundance of root-feeding nematode in the pearl millet (the tested cover crop in our study) rhizosphere than in the native weeds rhizosphere, even the pearl millet being classified as a host-plant of root-feeding soil nematode accordingly to McSorley (1999), Bagayoko et al. (2000), Timper and Hanna (2005), Inomoto et al. (2007) and Dias-Arieira et al. (2009).

Some studies have showed that host-plant diversity by soil nematodes can increase this soilborne pest group, which are feedback mechanisms influencing subsequent plant growth (Wardle et al., 2004; Wood et al., 2015; Van der Putten et al., 2016). When we reduce the diversity of these host-plants by soil nematodes and introduce a cover crop to maintain the plant residues production combined with crop rotation in time, we can reduce the abundance of rootfeeding soil nematode and increase free-living soil nematode in time (Tiemann et al., 2015). Thus, smallholder farmers can employ positive plant-soil-feedbacks without losing the farming season by waiting soil nematode community homeostasis. Dense-rooting and productive cover crops (i.e., non-legume plant species) can improve soil organic carbon (Souza et al. 2018). Although growing plants stimulate plant-feeding soil nematodes (Barel et al., 2017), careful reduction of host-plants by root-feeding nematodes can reduce specific nematode species (Fourier et al., 2016).

Our aims with this study were: (i) to investigate the effects of long-term cultivation of a non-legume plant species (Pennisetum glacum (L.) R.Br.) as a cover crop on the abundance of soil nematodes in a Regosol; (ii) to determine whether a local history of non-legume plant species cultivation are associated with reduced root-feeding soil nematodes; (iii) to compare the abundance of soil nematodes in natural ecosystem (i.e., Caatinga moist forest enclaves) and agroecosystem (i.e., P. glaucum). To accomplish these, we combined a field sampling of three different soil rhizosphere types, i.e., non-legume plant species and native weeds, characterized the soil chemical properties (i.e., soil $\mathrm{pH}$, soil organic carbon, total nitrogen and available $\mathrm{P}$ ) and abundance of soil nematodes (i.e., free-living soil nematode and root-feeding soil nematode).

\section{Material and Methods}

This study was conducted at the Agrarian Science Centre, Federal University of Paraiba, using a long-term field experiment at the "Chãde-Jardim" Experimental Station (06 58 '12" S, $35^{\circ} 42^{\prime} 15^{\prime \prime} \mathrm{W}$, altitude $619 \mathrm{~m}$ ) comprising an old camp of sweet potato [Ipomoea batatas (L.) Lam] that was abandoned during 2013 through high abundance of root-knot nematodes. The climate is Tropical wet and dry type (As' accordingly Köppen classification), with average annual precipitation and temperature of $1,500 \mathrm{~mm}$ and $21^{\circ} \mathrm{C}$, respectively. Data on historic of land use and the climatic conditions of the study area has been described in more detail by Souza et al. (2018).

The soil at the experimental field was classified as a Regosol (WRB, 2006). Soil samples were collected at the dry period (April 2017). Thirty soil samples were collected from a depth of 0-20 cm, air-dried and passed through a $2-\mathrm{mm}$ sieve. Soil $\mathrm{pH}$ was measured in a suspension of soil and distilled water (1:2.5 v:v, soil: water suspension) (Black, 1965). Total organic carbon was determined by rapid dichromate oxidation method according to the methodology described by Okalebo et al. (1993). To quantify total nitrogen, soil samples were first digested with sulphuric acid plus potassium 
sulphate and we then followed the protocol described in Kjeldahl (Black, 1965). Available phosphorus (Olsen's P) was determined colorimetrically using a spectrophotometer at 882 $\mathrm{nm}$ by extraction with sodium bicarbonate for 30 min (Olsen et al., 1954). The chemical characteristics of the soil site before the beginning of the experiment are in given in Table 1.

Table 1 Soil chemical characteristics $(0-20 \mathrm{~cm})$ before to start the experiment $(N=30 \pm \mathrm{SD})$

\begin{tabular}{lccc}
\hline Soil chemical characteristics & P. glaucum & Native weeds & Caatinga moist-forest enclaves \\
\hline Soil $\mathrm{pH}\left(1: 2.5 \mathrm{Soil}: \mathrm{H}_{2} \mathrm{O}\right)$ & $5.70 \pm 0.05$ & $5.38 \pm 0.02$ & $5.50 \pm 0.11$ \\
Available $\mathrm{P}\left(\mathrm{mg} \mathrm{dm}^{-3}\right)$ & $36.00 \pm 0.98$ & $5.51 \pm 0.13$ & $11.01 \pm 2.01$ \\
Total organic carbon $\left(\mathrm{g} \mathrm{kg}^{-1}\right)$ & $7.40 \pm 0.15$ & $2.94 \pm 0.09$ & $6.96 \pm 1.16$ \\
Total nitrogen $\left(\mathrm{g} \mathrm{kg}^{-1}\right)$ & $0.61 \pm 0.01$ & $0.21 \pm 0.01$ & $0.34 \pm 0.11$ \\
\hline
\end{tabular}

We performed a field study in this area from April to September 2017. Thus, we used an area of $768 \mathrm{~m}^{2}$ which was cultivated with cover crop for 3 consecutive years before starting this experiment. Three treatments were allocated in a randomized block design that consisted of: (1) cover crop - that consisted of pearl millet plants (P. glaucum (L.) R.Br.); (2) negative control that consisted of native weeds; and (3) positive control - that consisted of Caatinga moist-forest enclaves. Each treatment plot $(6 \times 4 \mathrm{~m})$ was replicated in four blocks, and to our analysis we extracted for each plot 20 rhizosphere samples. To better simulate the smallholder farming systems commonly used in Paraiba, Brazil, no dolomitic limestone and any chemical or organic compound were added to the treatments. This farming system in our studied region is characterized by no inputs of limestone, fertilizer, herbicide or pesticide and by its low harvest yield for annual crops such as $P$. glaucum. The cover crop was sown at a seedling rate of 300 seed $\mathrm{m}^{-2}$ at a $3 \mathrm{~cm}$ depth and the plots were spaced $0.5 \mathrm{~m}$ between them. The Caatinga moist-forest enclaves plots were placed at $500 \mathrm{~m}$ adjacent to our field experiment.

Soil nematodes were extracted by the wet sieving technique (Gerdemann and Nicolson, 1963) followed by sucrose centrifugation (Jenkins, 1964). For this, we used $100 \mathrm{~g}$ of rhizosphere samples obtained from each of the three treatments. Initially, the extracted nematodes were examined in water under a dissecting microscope and they were separated based on their life cycle (free-living nematodes and root-feeding nematode). In addition to soil nematodes life cycle identification, we also assessed soil nematode abundance by counting the total number of soil nematodes of each soil nematode group by recording the number of soil nematodes in the samples.

The main differences between the studied treatments (pearl millet plants, native weeds and Caatinga moist-forest enclaves) on soil nematode abundance were analysed by means of a one-way ANOVA. Comparisons of means after one-way ANOVA were performed using Tukey's HSD post-hoc comparison test $(P<0.05)$. Differences in soil nematode groups were determined by nonparametric $t$ test followed by Monte Carlo test (100 replicates). Data set no meeting assumptions for ANOVA were transformed as required (logarithmic). Results are presented here in their original scale of measurement (mean and standard deviation) (Zar, 1984). Univariate analyses ( $t$ test, one-way ANOVA, and Tukey's test) were performed using R software.

\section{Results and Discussion}

For all studied treatments the soil nematode group abundance was significantly different between free-living nematode and root-feeding nematode soil groups. The abundance of freeliving nematode group was higher in the Caatinga moist-forest enclaves, and this do not differ to $P$. glaucum plots. Whereas the highest root-feeding nematode abundance was found in the native weeds treatment (Table 2).

Our results provided evidence for changes in both the abundance of root-feeding and freeliving soil nematodes caused by long-term cultivation of non-legume plant species. In fact, $P$. glaucum cultivation may influence both soil nematode functional group abundance as described by Bagayoko et al. (2000) and Barel et 
al. (2017). These results support our hypothesis that a non-legume plant species $(P$. glaucum) as cover crop may positively impact the abundance of free-living soil nematode by reducing the abundance of host-plants (e.g., native weeds) by root-feeding soil nematode in a long-term field study on a Regosol. It is not usual to report the use of $P$. glaucum plants as a biocontrol to soil nematodes (Inamoto et al., 2007; Zhang et al., 2018a), but results herein showed that pearl millet cultivation also may impact positively the abundance of root-feeding soil nematode (Timper and Hanna, 2005). Zhang and co-workers (2018b) reported that native plants may affect soil food webs through various resource inputs including shoot litter, root litter and living root input, which in turns impact soil nematode abundance.

Table 2 Abundance of soil nematode groups of the studied treatments (mean $\pm \mathrm{SD}, N=80$ )

\begin{tabular}{|c|c|c|}
\hline $\begin{array}{l}\text { Sites/Soil } \\
\text { groups }\end{array}$ & nematode & $\begin{array}{l}\text { Abundance } \\
\text { (nematodes per } 100 \mathrm{~g} \\
\text { of soil) }\end{array}$ \\
\hline
\end{tabular}

\begin{tabular}{lc}
\hline Free-living nematode & \\
P. glaucum & $17.00 \pm 1.24 \mathrm{a}^{1}$ \\
Native weeds & $3.13 \pm 0.28 \mathrm{~b}$ \\
$\begin{array}{l}\text { Caatinga moist-forest } \\
\text { enclaves }\end{array}$ & $21.00 \pm 2.06 \mathrm{a}$ \\
\hline Root-feeding nematode & \\
$\begin{array}{l}\text { P. glaucum } \\
\text { Native weeds }\end{array}$ & $21.00 \pm 1.04 \mathrm{~b}$ \\
Caatinga moist-forest \\
enclaves
\end{tabular}

Free-living nematode vs. $16.32 * *$

Root-feeding nematode ${ }^{2}$

${ }^{1}$ Same letters represent no significant differences by Tukey's test $(P<0.05) .{ }^{2}$ Independent sample $t$ test comparing freeliving nematode $\mathrm{x}$ root-feeding nematode soil groups.

For the total soil nematode abundance (Figure 1 ), we found the highest abundance of this soil organism group in both the $P$. glaucum and native weeds treatments, followed in a decrescent order by Caatinga moist-forest enclaves (lower 41.53 $\%)$.

Our results on total soil nematode abundance indicated that this component cannot be considered as a bioindicator for soil quality or even disturbance of soil nematode functional groups. This finding suggests that total soil nematode abundance experienced the same effects of $P$. glaucum and native weeds. These results do not agree with previous work done by McSorley (1999), who concluded that pearl millet plants were considered poor hosts compared with other annual plant species. The living rootderived resource of a specific host-plant can greatly influence most soil biotic groups (Eissfeller et al. 2013). Our study demonstrated indirectly that the differences of living root input among $P$. glaucum, native weeds and Caatinga moist-forest enclaves affected total abundance of soil nematode at both soil nematode functional group (root-feeding soil nematode and free-living soil nematode). Accordingly, Dias-Arieira (2009), the living roots may affect the abundance of soil nematode during growing seasons. Our study found that the total abundance of soil nematodes was $43.21 \%$ less in the Caatinga moist-forest enclaves compared with $P$. glaucum plots, which the rhizosphere soil samples were collected during the flowering season of the studied annual crop species.

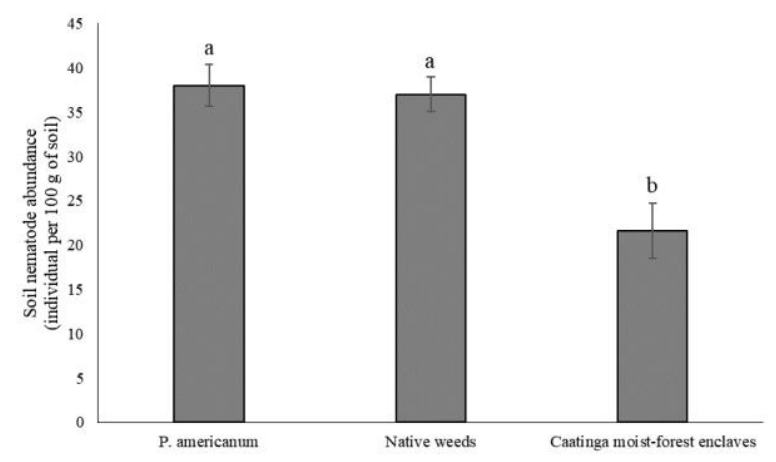

Figure 1 Total soil nematode abundance of the studied treatments (mean $\pm \mathrm{SD}, N=80$ ). Different letters indicate significant differences among the studied treatments by Tukey's test after performing one-way ANOVA $(P<0.05)$.

\section{Conclusion}

The long-term use of a non-legume cover crop did not decrease total abundance of soil nematodes on a Regosol after 3 years of its consecutive cultivation. We did not find any difference between the abundance of free-living soil nematode in the non-legume cover crop (e.g. $P$. glaucum) and the Caatinga moist-forest enclaves treatment. In most of the agricultural systems, the root-feeding nematodes are the main problem responsible for the crop yield decline. The pearl millet as a host-plant by root-feeding soil nematode, even this cover crop has improved 
the abundance of free-living nematode. Our results also highlight the importance of considering the identification of soil nematode groups in a sandy soil as indicator of soil quality and impacts of soil management.

\section{Acknowledgement}

The authors gratefully acknowledge the support, generosity, use of services and facilities of the "Programa de Pós-Graduação em Ciência do Solo" without which the present study could not have been completed, and CAPES for the postdoctoral fellowship granted to the first author.

\section{References}

Bagayoko, M.; Buerkert, A.; Lung, G.; Bationo, A.; Römheld, V. Cereal/Legume rotation effects on cereal growth in Sudano-Sahelian West Africa: soil mineral nitrogen, mycorrhizae and nematodes. Plant and Soil, v. 218, n. 1-2, p. 103-116,

2000 . https://doi.org/10.1023/A:1014957605852

Barel, J. M.; Kuyper, T. W.; de Boer, W.; Douma, J. C.; de Deyn, G. B. Legacy effects of diversity in space and time driven by winter cover crop biomass and nitrogen concentration. Journal of Applied Ecology, v. 55, n. 1, p. 299-310, 2018. https://doi.org/10.1111/1365-2664.12929

Black, C. A. Methods of soil analysis, Part 2. In: Black C. A. (Ed.). Agronomy Monograph No. 9. Madison, WI: American Society of Agronomy, $1965 . \quad$ p. 771-1572. https://doi.org/10.2134/agronmonogr9.2.index

Dias-Arieira, C. R.; Ferraz, S.; Ribeiro, R. C. F. Reação de gramíneas forrageiras a Pratylenchus brachyurus. Nematodologia brasileira, v. 33, n. $1, \quad$ p. 90-93, 2009. http://docentes.esalq.usp.br/sbn/nbonline/ol\%20331/9093\%20co.pdf

Droppelmann, K. J.; Snapp, S. S.; Waddington, S. R. Sustainable intensification options for smallholder maize-based farming systems in sub-Saharan Africa. Food Securite, v. 9, n. 1, p. 133-150, 2017. https://doi.org/10.1007/s12571-0160636-0

Eissfeller, V.; Beyer, F.; Valtanen, K.; Hertel, D.; Maraun, M.; Polle, A.; Scheu, S. Incorporation of plant carbon and microbial nitrogen into the rhizosphere food web of beech and ash. Soil Biology and Biochemistry, v. 62, p. 76-81, 2013. https://doi.org/10.1016/j.soilbio.2013.03.002
Fourie, H. A. P.; Lammers, J.; Daneel, M. Brassicacea-based management strategies as an alternative to combat nematode pests: A synopsis. Crop Protection, v. 80, p. 21-41, 2016. https://doi.org/10.1016/j.cropro.2015.10.026

Geisen, S.; Snoek, L. B.; Hooven, F. C. T.; Duyts, H.; Kostenko, O.; Bloem, J.; Martens, H.; Quist, C. W.; Helder, J. A.; van der Putten, W. H. Integrating quantitative morphological and qualitative molecular methods to analyse soil nematode community responses to plant range expansion. Methods in Ecology and Evolution. v. 80, p. 1-13, 2018. https://doi.org/10.1111/2041-210X.12999

Gerdemann, J. W.; Nicolson, T. H. Spores of mycorrhizal Endogone species extracted from soil by sieving and decanting. Transactions of the British Mycological Society, v. 46, n. 2, p. 235-244, 1963. https://doi.org/10.1016/S00071536(63)80079-0

Hilton, S.; Bennett, A. J.; Chandler, D.; Mills, P.; Bending, G. D. Preceding crop and seasonal effects influence fungal, bacterial and nematode diversity in wheat and oilseed rape rhizosphere and soil. Applied Soil Ecology, v. 126, p. 3446, 2018. https://doi.org/10.1016/j.apsoil.2018.02.007

Inomoto, M. M.; Machado, A. C. Z; Antedomênico, S. R. Reação de Brachiaria spp. e Panicum maximum a Pratylenchus brachyurus. Fitopatologia Brasileira, v. 32, n. 4, p. 341-344, 2007. http://www.scielo.br/pdf/fb/v32n4/09.pdf

Jenkins, W. R. A rapid centrifugal flotation technique for separation nemathodes from soil. Plant Disease Report, v. 48, n. 9, p. 692, 1964. https://www.cabdirect.org/cabdirect/abstract/1965080110 5

McSorley, R. Host suitability of potential cover crops for root-knot nematodes. Supplement to the Journal of Nematology, v. 31, n. 4S, p. 619-623, 1999. https://www.ncbi.nlm.nih.gov/pmc/articles/PMC2620418

Okalebo, J. R.; Gathus, K. W.; Woomer, P. L. Laboratoty methods of plant and soil analysis: A working manual. Technical Bulletin No. 1 Soil Science Society East Africa. Nairobi: Kenya, 1993. 88p. http://hdl.handle.net/11295/85257

Olsen, S. R.; Cole, C. V.; Watanable, F. S.; Dean, L. A. Estimation of available phosphorous in soil by extraction with sodium bicarbonate. Washington, DC: US Department of 
Agriculture, $\quad 1954 . \quad 24 p$. https://archive.org/details/estimationofavai939olse

Souza, G. A. V. S.; Souza, T. A. F.; Santos, D.; Rios, E. S.; Souza, G. J. L. Agronomic evaluation of legume cover crops for sustainable agriculture. Russian Agricultural Science, v. 44, n. $1, \quad$ p. $31-38,2018$. https://doi.org/10.3103/S1068367418010093

Tiemann, L. K.; Grandy, A. S.; Atkinson, E. E.; Marin-Spiotta, E.; McDaniel, M. D. Crop rotational diversity enhances belowground communities and functions in an agroecosystem. Ecology Letters, v. 18, n. 8, p. 761-771, 2015. https://doi.org/10.1111/ele. 12453

Timper, P. and Hanna, W. W. Reproduction of Belonolaimus longicaudatus, Meloidogyne javanica, Paratrichodorus minor, and Pratylenchus brachyurus on Pearl Millet (Pennisetum glaucum). Journal of Nematology, v. 37, n. 2, p. 214-219, 2005. https://www.ncbi.nlm.nih.gov/pmc/articles/PMC2620950 /

van der Putten, W. H.; Bradford, M. A.; Pernilla, B. E.; van de Voorde, T. F. J.; Veen, G. F. Where, when and how plant-soil feedback matters in a changing world. Functional Ecology, v. 30, n. 7, p. 1109-1121, 2016. https://doi.org/10.1111/1365-2435.12657

Wardle, D. A.; Bardgett, R. D.; Klironomos, J. N.; Setälä, H.; van Der Putten, W. H.; Wall, D. H.
Ecological linkages between aboveground and belowground biota. Science, v. 304, n. 5677, p. 1629-1633,

https://doi.org/10.1126/science.1094875

Wood, S. A.; Karp, D. S.; DeClerck, F.; Kremen, C.; Naeem, S.; Palm, C. A. Functional traits in agriculture: Agrobiodiversity and ecosystem services. Trends in Ecology and Evolution, v. 30, n. 9, p. 531-539, 2015. https://doi.org/10.1016/j.tree.2015.06.013

WRB, IUSS, Working Group. World reference base for soil. World Soil Resour. Rep., no 103. 2006, 145 p. http://www.fao.org/3/a-a0510e.pdf

Zar, J. H. Biostatistical analysis. Prentice Hall, Englewood Cliffs. 1984, 718p. http://studylib.net/doc/18402354

Zhang, L. P.; Peng, D. L.; Wang, X. L.; Kong, L. A.; Peng, H.; Liu, S. M.; Liu, Y.; Huang W. K. Priming effect of root-applied silicon on the enhancement of induced resistance to the rootknot nematode Meloidogyne graminicola in rice. BMC Plant Biology. v. 18, n. 50, p. 1-12, 2018a. https://doi.org/10.1186/s12870-018-1266-9

Zhang, P.; Neher, D. A.; Li, B.; Wu, J. The impacts of above- and belowground plant input on soil microbiota: Invasive Spartina alterniflora versus native Phragmites australis. Ecosystems. v. 21, n. 3, p. 469-481, 2018b. https://doi.org/10.1007/s10021-017-0162-8 